\title{
Стереотип еврея в украинской и английской прозе І-й половины XIX в.
}

\author{
Денис Чабович Чик
}

\begin{abstract}
Аннотация
В статье раскрывается тема моделирования стереотипа еврея в украинской и английской литературе первой половины XIX в. В статье доказывается, что образ еврея в художественных текстах В. Скотта, Ч. Диккенса, О. Сомова, Г. Квитки-Основьяненко, П. Кулиша, Е. Гребенки часто является прототипом злодея, который происками и уловками пытается ужиться со своими нынешними или бывшими обидчиками и часто - их провести и уничтожить. В то же время он является униженным и бесправным изгоем в христианской общине, человеком «низшего сорта», и даже при условии частичной интеграции в общество, эта «родимая» примета постоянно подчеркивается авторами. Образы же «прекрасных евреек» Ребекки и Татьяны и их судьбы (романы В. Скотта и П. Кулиша) - это демонстрация глубокой «культурно-исторической» пропасти между ними и их любимыми - представителями христианской культуры.
\end{abstract}

\section{Ключевые слова}

стереотип; историческая проза; образ еврея; имагология

\section{Abstract \\ The Jew Stereotype in the Ukrainian and English Historical Prose of the First Half of the $19^{\text {th }}$ Century}

The article deals with the theme of modelling the Jew stereotype in the Ukrainian and Russian literature of the first half of the XIX cent. In the paper we prove that the Jew image in the literary texts of W. Scott, Ch. Dickens, O. Somov, G. Kvitka-Osnovianenko, P. Kulish, Ye. Grebinka is often the prototype of a villain who intrigues and tricks trying to get on with his current or ex-offenders, and often - to deceive and destroy them. At the same time, he is humiliated and powerless pariah in the Christian community, a man of the "lower class", and even with the partial integration in society, this "mole sign" is constantly emphasized by the authors. Images of the "beautiful" Jewish women Rebecca and Tatiana and their fate (the novels of W. Scott and P. Kulish) express the deep "culturalhistorical" gap between them and their loved ones - representatives of Christian culture.

\section{Key words}

stereotype; historical fiction; the image of the Jew; imagology 
Стереотипы - «застывшие образы» (по выражению В. Хорева), - будучи по своей природе образами ирреальными, обладают исключительной способностью убеждать благодаря легкости их восприятия. ${ }^{1}$ Художественная литература является одним из материалов исследования форм экспликации стереотипов, иллюстрацией их ментальной основы, что позволяет в призме прошлых представлений увидеть степень укоренения и истоки современной перцепции.

В предоставленной статье мы хотели бы коснуться имагологического аспекта, который отражает всю сложность «еврейского вопроса» в произведениях украинской литературы первой половины XIX в. Изо всех литературоведческих работ, касающихся этой проблематики, самыми содержательными, по нашему мнению, является статья Г. Грабовича «Еврейская тема в украинской литературе XIX и начала XX века» ${ }^{2}$ и монография канадского украиниста М. Шкандрия «Jews in Ukrainian Literature: Representation and Identity ` $^{3}$ без преувеличения заполнившая пробел в исследованиях образа еврея в украинской литературе, и в то же время продемонстрировавшая перспективность и неисчерпаемость этой научной проблемы. Специфики изображения стереотипа еврея в украинской литературе первой половины XIX в. касаются частично современные литературоведы, в частности, М. Вайскопф в монографии «Покрывало Моисея. Еврейская тема в эпоху романтизма», ${ }_{4}^{4}$. Кац в «Neither with Them, nor without Them: the Russian Writer and the Jew in the Age of Realism», ${ }^{5}$ Л. Ливак в исследовании "The Jewish Persona in the European Imagination: a Case of Russian Literature» ${ }^{6}$ и др.

В англоязычном литературоведческом дискурсе, в отличие от украинского, тема моделирования стереотипов еврея в английской литературе XIX в. широко рассматривалась в монографических исследованиях и статьях. К важным исследованиям следует отнести работы $Ф$. М. Монтегью «The Jew in the Literature of England to the End of the 19th Century»" Е. Розенберга "From Shylock to Svengali; Jewish Stereotypes in English Fiction», ${ }^{8}$ Е. Паниц «The Alien in Their Midst: Images of Jews in English Literature», ${ }^{9}$. . Кауф-

1 CHOREV, V.: Imagologija i izučenije russko-pol'skich literaturnych svjazej. In: CHOREV, V. A. (otv. red.): Poljaki i russkije v glazach drug druga, Moskva: Indrik, 2000, s. 23.

2 HRABOVIČ, H.: Jevrejs'ka tema v ukrajins'kij literaturi XIX ta počatku XX storiččja. In: HRABOVIČ, H.: Do ìstoriï ukrajins'koji lìteraturì: Doslìdžennja, ese, polemika. K.: Osnovì, 1997, s. 238-258.

3 SHKANDRIJ, M.: Jews in Ukrainian Literature: Representation and Identity. New Haven: Yale University Press, 2009.

4 VAJSKOPF, M.: Pokryvalo Moiseja. Jevrejskaja tema v èpochu romantizma. Moskva: Mosty kul'tury - Gešarim, 2008.

5 KATZ, E. M.: Neither with Them, nor without Them: the Russian Writer and the Jew in the Age of Realism. Syracuse, N.Y.: Syracuse University Press, 2008.

6 LIVAK, L.: The Jewish Persona in the European Imagination: a Case of Russian Literature. Stanford, Calif.: Stanford University Press, 2010.

7 MONTAGU, F. M.: The Jew in the Literature of England to the End of the 19th Century. New York: Meridian Books, 1960.

8 ROSENBERG, E.: From Shylock to Svengali; Jewish Stereotypes in English Fiction. Stanford, Calif.: Stanford University Press, 1960.

9 PANITZ, E. L.: The Alien in Their Midst: Images of Jews in English Literature. Rutherford [N. J.]: Fairleigh Dickinson University, 1981. 
ман «English Origins, Jewish Discourse, and the Nineteenth-Century British Novel: Reflections on a Nested Nation», ${ }^{10}$ M. Г. Скривенера "Jewish Representation in British Literature 1780-1840: after Shylock», ${ }^{11}$ Ш. А. Спектор «The Jews andBritish Romanticism», ${ }^{12}$ Дж. В. Пейдж «Imperfect Sympathies: Jews and Judaism in British Romantic Literature and Culture», ${ }_{13}^{13}$ Дж. М. Егана "The Stereotyped Jew: in English Literature», ${ }^{14}$ коллективную монографию "Jewish Presences in English Literature» под редакцией Д. Когена и Д. Хеллер,$^{15}$ а также ряд других.

В упомянутом выше исследовании «Еврейская тема в украинской литературе XIX и начала $X X$ века» Г. Грабович предлагает три главные модели восприятия евреев, которые, по мнению ученого, могут служить своеобразной периодизацией «еврейской темы» в украинской литературе: стереотипная, социально-нравственная («реалистическая») и политико-этическая. ${ }^{16}$ Ученый рассматривает особенности изображения образа еврея начиная от «Истории Русов или Малой России» и заканчивая драмой «Между двух сил» В. Винниченко, а касательно прозы XIX в. останавливается на творчестве П. Кулиша и И. Франко, вспомнив также повесть «Тарас Булъба» Н. Гоголя и роман «Чайковский» Е. Гребенки.

В украинской литературе этого периода, как считает исследователь, доминирует стереотипная модель восприятия еврея: начиная с образов евреев-прислужников польской шляхты в трактате «История Русов или Малой России», карикатурного образа Янкеля в повести «Тарас Бульба» Н. Гоголя и образа негодяя Герцика из романа «Чайковский» Е. Гребенки, заканчивая двумерным стереотипом Лейбы в поэме «Гайдамаки» Т. Шевченко и евреев-доносчиков из драмы «Колии. Украинскал драма с последнего польского господства на Украине» П. Кулиша. Впрочем, ранняя проза П. Кулиша в работе Г. Грабовича не рассматривается. Дополнение этого ряда романом «Михаил Чарнишенко...» и другими произведениями украинских писателей первой половины XIX в. разрешит конкретизировать тип моделирования образа еврея, а сопоставление с соответствующими репрезентациями в английской литературе позволит обратить внимание на национальные особенности восприятия еврейства в обеих культурах, проследить общее и несходное в формировании этнического стереотипа восприятия евреев украинцами и англичанами, его специфику в обозначенный период, а также трансформацию качеств стереотипа в авторских интерпретациях. Другими словами, мы попробуем наряду со стереотипами, выяснить и причины, по которым евреи в Украине и Англии имели статус мецоры -

10 KAUFMAN, H.: English Origins, Jewish Discourse, and the Nineteenth-Century British Novel: Reflections on a Nested Nation. University Park, Pa.: Pennsylvania State University Press, 2009.

11 SCRIVENER, M. H.: Jewish Representation in British Literature 1780-1840: after Shylock. New York: Palgrave Macmillan, 2011.

12 SPECTOR, Sh. A.: The Jews and British Romanticism. New York: Palgrave Macmillan, 2005.

13 PAGE, J. W.: Imperfect Sympathies: Jews and Judaism in British Romantic Literature and Culture. New York: Palgrave Macmillan, 2004.

14 EGAN, J. M.: The Stereotyped Jew: in English Literature. [Philadelphia, Pa.]: Xlibris, 2002

15 COHEN, D. - HELLER, D. (eds.): Jewish Presences in English Literature. Montreal [Que.]: McGill-Queen's University Press, 1990.

16 HRABOVIČ, H.: Jevrejs'ka tema v ukrajins'kij literaturi XIX ta počatku XX storiččja. In: HRABOVIČ, H.: Do ìstorìi ukrajins'koji lìteraturì: Doslìdžennja, ese, polemika. K.: Osnovì, 1997, s. 241. 
в иудейской Торе человек, которого считали «прокаженным» в обществе, проклятым за свои грехи, в первую очередь - за злословие и распространение ложных слухов. Такого человека следовало изолировать по двум причинам: для того, чтобы прекратить его нездоровое влияние на общество, и для личного раскаяния. ${ }^{17}$

Стереотип понимаем как специфическую форму восприятия, которая накладывает отпечаток на получаемую информацию задолго до ее обработки. ${ }^{18}$ Такая перцепция насыщенная не личным опытом, а традицией, то есть компонентом общественного сознания, коллективного разума, который вырабатывает упрощенные представления о других этносах, ведь так удобнее вписывать их в общую картину мировоззрения. Стереотип - это систематизированный образ, который не только изображает мир, но и помогает делать якобы «собственные» умозаключения. Как считает В. Липпман, «стереотипь нагружены преференчиями, любовъю или неприязнъю, ассочиируются со стра хами, желаниями, влечениями, гордостью, надеждой. Объект, который активизирует стереотип, оценивается в связи с соответствующими эмочиями». ${ }^{19}$ Таким образом, появление этнических стереотипов в художественной литературе является плодом не только традиционных в той или иной общине представлений, но и авторской оценки этого «правильного» умозаключения или взгляда на фигуру Чужого.

Четырехкомпонентная структура стереотипов была определена американским психологом А. Л. Эдвардсом еще в 1940 г. И с тех пор успешно используется для анализа этностереотипов: однородность (uniformity) - общность характеристик, которыми наделяют этнос; направленность (direction) - общее восприятие объекта стереотипизации - положительное или отрицательное; интенсивность (intensity) - степень предубеждения, который выводится по оценке характеристик, приписываемых этносу; качество (quality) - специфика характеристик этноса. ${ }^{20}$ Эти компоненты в структуре этнических стереотипов в рассказе «Гайдамак» (1825) О. Сомова, повести «Предания о Гаркуше» (1842) Г. Квитки-Основьяненко, романах «Михаил Чарнишенко...» (1843) П. Кулиша, «Чайковский» (1843) Е. Гребенки, а также в романах В. Скотта [«Ivanhoe» (1820), «The Surgeon's Daughter» (1827)] и Ч. Диккенса [«Oliver Twist; or, The Parish Boy’s Progress» (1838), «Our Mutual Friend» (1864-1865)] мы рассмотрим в компаративном аспекте. До сих пор сравнительно-типологическое сопоставление этих произведений в ближайшей плоскости не становилось предметом исследовательского внимания.

На формирование негативных этностереотипов образа евреев в коллективном сознании Англии и Украины повлияли определенные исторические факты, на которых остановимся подробнее, ведь именно они определяют и объясняют основу стереотипных моделей образов евреев в исследуемых произведениях.

В Англии первой половины XIX в. правовой статус евреев, закрепленный еще в протекторате О. Кромвеля, был, по сравнению с Украиной, достаточно высо-

17 Tora. Pjatiknižije i Gaftarot. Moskva - Ijerusalim: Gešarim, 1999, s. 634.

18 LIPPMAN, U.: Obščestvennoje mnenije. Moskva: Institut Fonda «Obščestvennoje mnenije», 2004, s. 110.

19 Ibidem, s. 128.

20 EDWARDS, A. L.: Four Dimensions in Political Stereotypes. Journal of Abnormal and Social Psychology, 1940, Vol. 35 (4), pp. 566-572. 
ким. Евреи, рожденные на территории королевства, считались британскими подданными с территориально неограниченным правом жительства, а их притеснения, скажем, в избирательных или профессиональных правах, были такими же, как и в отношении католиков. Впрочем, в сознании рядового англичанина образ еврея формировался под влиянием христианской традиции и народных предрассудков. ${ }^{21}$ Такой стереотип порождал, несмотря на толерантное отношение государства, даже настоящие парламентские дебаты. В 1753 году, после принятия билля, который позволял натурализацию евреев через определенный срок пребывания в Британии, в обществе поднялось настоящее сопротивление «еврейскому закону» - настолько мощное, что билль отменили, а к законодательному расширению прав евреев английский парламент вернулся только в начале 1830-х годов.

Современные исследователи отрицают существование в украинцев XVIII - первой половины XIX в. агрессивного антисемитского стереотипа. Отчуждение между украинцами и евреями имело устойчивый характер и было основано на кардинальном различии систем ценностей: религиозное начало (евреи в сознании тогдашних украинцев - прежде всего «потомки» убийц Христа, их религия - определенно антихристианская, а потому дьявольская), образ жизни (был связан с объективными причинами - постоянными запретами заниматься сельским хозяйством и слухами о жизни в закрытых для христиан гетто), поведенческие стереотипы («хитрые евреи» всегда обманывают и предают христиан), определенное место в социальноэкономическом строении общества (формирование сферы «еврейских» профессий - торговля, посредничество, аренда, право, банковское и таможенное дело). Соответственно, в украинском фольклоре еврей - это, как правило, негативный, реже - иронический образ с определенным набором «плохих» качеств. В. Нахманович констатирует, что в то время как «народом был произведен философский подход, позволяюший спокойно и обвективно оченить место евреев в истории и современной жизни, обозначить сферы возможного взаимодействия, отработать модели в целом бесконфликтного сосуществования», можно заметить откровенно враждебную по сравнению с народной, интерпретацию евреев как «служителей зла» и глорификацию казацких погромов XVII - XVIII вв. в поэзии Т. Шевченко и фольклорных и публицистических трудах М. Драгоманова. ${ }^{22}$ Для объективности отметим, что в творчестве Т. Шевченко можно проследить эволюцию от поэтического «антисемитизма» к апологии еврейства в поздний период.

Таким образом, обозначим общие стереотипные модели восприятия евреев в Украине и Англии, сложившиеся в первой половине XIX века. Согласно идеи Ф. Зимбардо и М. Ляйппе, ${ }^{23}$ можем выделить три основные элементы такого восприятия - исторический, экономический и культурный - в представлении

21 KAC, Ja.: Ischod iz getto: social'nyj kontekst èmansipacii jevrejev, 1770-1870. Ijerusalim: Gešarim; Moskva: Mosty kul'tury, 2007, s. 20, 50.

22 NACHMANOVIČ, V.: Jevrei v ukrainskich narodnych pesnjach tret'jej četverti XIX v. 2011 [Èlektronnyj resurs] [Režim dostupa:] <http://historians.in.ua/index.php/doslidzhennya/46-nakhmanovich> [Data dostupa: 03.05.2015].

23 ZIMBARDO, F. - LJAJPPE, M.: Social'noje vlijanije. SPb.: Piter, 2000, s. 258. 
казаков и простолюдинов времен Хмельницкого евреи, невзирая на их социальный статус, были, наряду с польской шляхтой и униатами, злейшими врагами простого населения и православной веры, и потому подлежали преследованию и уничтожению. В стереотипах, которые доминировали среди англичан, преобладает экономический фактор - еврей становится прототипом хитрого и циничного бизнесмена, который не остановится перед строгим законом (как Божьим, так и моральным, и правовым) для обогащения. В Украине - это тип трактирщика или арендатора христианской церкви (показательной является характеристика евреяарендатора церкви в “Истории Русов или Малой России»- «Жиды, яко непримиримые враги христианства, те мировые бродяги и притча в человечестве, с увлечением взялисъ за такое надежное для них гадкое, но прибыльное дело и немедленно ключи иерковные и веревки колокольные отобрали себе в трактиры. При всякой надобности христианской должен староста идти к еврею, торговаться с ним и, по важности службы, платить за нее и выпросить ключи, а жид при том, насмеявшись вволю с богослужения христианского и обругав все, христианами почитаемое, называя его языческим, или, по-ихнему, поганским, приказывал старосте возвращать ему ключи под присягой, что ничего впрок не отправлено» ${ }^{24}$ ). Культурная составляющая в национальных стереотипах первой половины XIX в. не была весомой: культура и специфика жизни в еврейских семьях и общинах была terra incognita для абсолютного большинства христиан, как и знания об иудаизме.

В рассказе «Гайдамак» О. Сомова еврей Гершко выступает главным действующим лицом. Его друг Абрам - воплощение стереотипа еврея-торговца: он сказочно богат, но в то же время скрывает свое нечестно нажитое состояние и живет в внешне заброшенной хижине. Отбирая ценные вещи для продажи на ярмарке, Абрам боится их потерять, ведь перепродает добро, награбленное гайдамаками: «он беспрестанно прислушивался, озирался и при малейшем шуме снаружи бледнел, как Каин». ${ }^{25}$ Гершко утешает товарища, указывая на «особенность» их народа, обусловленную национальной психологией: «Опомнисъ! разве ты не еврей? Бог отнял у нас силу и смелость, а мы поневоле взялисъ за хитрость и пронърство». ${ }^{26}$ Еще одна характерологическая черта, которая приведет к гибели Гершка, - это жажда обогащения, которая ослепляет его инстинкт самосохранения (даже выкрест-гайдамак Лемет публично выражает свою любовь к золоту). Показательным в произведении является сравнение Абрама и Гершка с библейскими персонажами Каином и Иудой, - акцентируется подлое предательство в характерах евреев.

Образ еврея-выкреста, который тоже оказывается предателем, присутствует в «Предание о Гаркуше» Г. Квитки-Основьяненко. «Благородный разбойник» Гаркуша, несмотря на неоднократные предостережения своего товарища Бабы, верит безымянному еврею из своего отряда, уважая его хитрость и плутовство. Показательной является анонимность этого персонажа, которого все называют просто - «жид». Предвидения Бабы сбывается: «жид» предает Гаркушу, но получив плату

24 İstorija rusiv. K.: Veselka, 2003, s. 114-115.

25 SOMOV, O. M.: Kupalov večer: izbrannyje proizvedenija. K.: Dnipro, 1991, s. 25-26.

26 Ibidem, s. 26. 
за измену от лютого врага главаря гайдамаков - Городничихи - сам становится жертвой ее происков и получает заслуженное наказание.

В романе П. Кулиша «Михаил Чернышенко...» образ казака-выкреста - гадячского полковника Крыжановского - едва ли не единственный прототип реальной исторической личности. О Крыжановском упоминается в историко-политическом и отчасти публицистическом трактате «История Русов или Малой России», одном из главных исторических источников, который использовал П. Кулиш и часто цитировал в романе. Неофит Антон (до перехода в христианскую веру - Моисей) Крыжановский занимался откупами и арендой в гетманской администрации, а во время подготовки к предстоящей военной кампании согласился вербовать конный полк. До ее начала он уже имел немало имений и, получив именным указом Петра III от февраля 1761 г. должность бригадира Шлезвиг-Гольштейнского, уже меньше чем через год был назначен гадяцким полковником. После военного переворота, даже без опеки высокого покровителя, Крыжановский оставался на этом посту как минимум еще десять лет. ${ }^{27}$

П. Кулиш корректирует биографию полковника, дополняет ее «сербским» следом - чтобы связать с баном Радивоем - и романтическим ореолом демонического персонажа. Писатель завершает жизненный путь Крыжановского позорной смертью от руки мстительного Радивоя через применение характерного для романтизма литературного приема неожиданной драматической встречи, которая суммирует недоговоренные события.

Г. Грабович обращает внимание на интерес П. Кулиша к украинско-еврейским отношениям, особенно в его поэме «Украина» и поздней публицистике в журнале «Основа», отмечая при этом определенную эволюцию взглядов писателя от устоявшихся стереотипов о евреях - шинкарях и осквернителях православных церквей и православного обряда в целом (поэма «Украина», 1843 г.) или напыщенных, но одновременно запуганных доносчиков (незавершенная драма «Колии...», 1860 г.) к осуждению кровопролитных анти-еврейских погромов во времена гайдамаков на правобережной Украине в XVIII в. в полемической статье «Рисованная гайдаматчина». ${ }^{28}$ Такую же эволюцию во взглядах, напомним, прошел и Т. Шевченко.

Можно привести параллельный пример писательского видения «еврейского вопроса» в английской литературе - в творчестве Ч. Диккенса. Современники писателя обратили внимание на своеобразное подчеркивание национальности образа Фейгина, главаря лондонской воровской банды из раннего романа «Oliver Twist; or, The Parish Boy's Progress». Такое чрезмерное акцентирование на национальности, а не, скажем, на «профессиональной деятельности», дало основания обвинить Ч. Диккенса в антисемитизме, ведь в гротескном образе Фейгина выделено только три черты - жажда золота, коварство и жестокость. Стереотип богатого еврея исследователи видят и в саркастическом образе Әбенезера Скруджа с рождественского рассказа «A Christmas Carol in Prose, Being a Ghost Story of Christmas», ведь от

27 LAZAREVSKIJ, A. M.: Ljudi staroj Malorossii. 8. Kryžanovskije. Kijevskaja starina, 1885, № 5, Maj, s. 12-13.

28 HRABOVIČ, H.: Jevrejs'ka tema v ukrajins'kij literaturi XIX ta počatku XX storiččja. In: HRABOVIČ, H.: Do ìstoriì ukrajins'koji lìteraturì: Doslìdžennja, ese, polemika. K.: Osnovì, 1997, s. 246-248. 
«по-иудейски» принципиально не разделяет общего радостного празднования христианского Рождества. В одном из писем к своей читательнице-еврейке писатель был вынужден оправдываться, что образ Фейгина является реалистичным для времени, изображенного в романе, и, к тому же (что, очевидно, сомнительно), распространенным среди английских преступников. ${ }^{29} \mathrm{~B}$ конце концов, значительно позже, после очередной резкой критики, Ч. Диккенс изменил текст романа во избежание частого подтверждения национальности лондонского преступника, который, однако, как и архетипический ростовщик Шайлока из комедии «The Merchant of Venice» В. Шекспира, стал одним из самых ярких воплощений антисемитских стереотипов в художественной литературе. Как известно, в последнем завершенном романе «Our Mutual Friend» Ч. Диккенс изображает старого еврея Райя с насквозь положительными чертами, словно пытаясь оправдаться перед читателями. В романе есть немало примеров, подтверждающих попытки писателя опровергнуть ряд стереотипных заблуждений, как, например, убеждение в том, что иудеи ведут постоянную агрессивную религиозную агитацию среди христиан и являются меркантильными:

"'I could not have done it all, or nearly all, of myself,' said Lizzie. 'I should not have wanted the will; but I should not have had the power, without our managing partner.'

'Surely not the Jew who received us? ' said Mrs Milvey.

('My dear,' observed her husband in parenthesis, 'why not? ')

'The gentleman certainly is a Jew, 'said Lizzie, 'and the lady, his wife, is a Jewess, and I was first brought to their notice by a Jew. But I think there cannot be kinder people in the world.'

'But suppose they try to convert you!' suggested Mrs Milvey, bristling in her good little way, as a clergyman's wife.

'To do what, ma'am?' asked Lizzie, with a modest smile.

'To make you change your religion,' said Mrs Milvey.» (p. 512)..$^{30}$

Райя является полной противоположностью Фейгина: он добродетельный защитник обиженных детей, который ни при каких сложных обстоятельствах не думает только о себе. Этот, так сказать, анти-Шайлока, играет роль марионетки в руках хитрого ростовщика и мошенника Фледжби, который прикрывает собственные махинации. По меткому выражению Г. Стоуна, в попытке создать репрезентативный образ хорошего еврея, Ч. Диккенс формирует странную смесь сказочного волшебника и библейского мудреца. ${ }^{31}$ В итоге, этому образу не хватает жизненности, а его мудрость трудно согласуется со слепой покорностью Фледжби. Так или иначе, все три попытки Ч. Диккенса вывести реалистичный образ еврея - с соответствующим доминированием в характерах жажды, добродетели или

29 HOWE, I.: Introduction. In: DICKENS, Ch.: Oliver Twist. New York: Bantam Dell, 2005, pp. XIX.

30 DICKENS, Ch.: Our Mutual Friend [Электронный ресурс] [Режим доступа:] <http:// www2.hn.psu.edu/ faculty/jmanis/dickens/friendco.pdf> [Дата доступа: 03.05.2015].

31 STONE, H.: Dickens and the Jews. Victorian Studies, 1959, Vol. 2, No. 3, pp. 248. 
иудейского отрицание христианских праздников - были неудачными из-за присущей им однобокости. ${ }^{32}$

Вернемся к анализу образа Крыжановского. В. Петров замечает, что образ полковника-выкреста является центральным в романтической интриге романа «Михаил Чарнишенко...», ведь связан со всеми персонажами и, по мнению ученого, «берет свое начало от Исаака Вальтер-скоттовского». ${ }^{33}$ Впрочем, Исаак с «Ivanhoе» В. Скотта вполне противоположен типажу: он - ростовщик, вынужден быть очень осторожным и хитрым, чтобы сохранить богатство, а часто - поскольку бесправный - свою жизнь и жизнь близких. Его хитрость и жажда граничат с симбиотическим приспособлением к суровым реалиям жизни, во времена средневековой Англии не было благосклонным к «христоубийцам». Интересно, что В. Скотт едва ли не впервые в английской литературной традиции конструирует образ ростовщика с сознательным выражением авторского сочувствия к судьбе еврейского народа: «... for, except perhaps the flying fish, there was no race existing on the earth, in the air, or the waters, who were the object of such an unintermitting, general, and relentless persecution as the Jews of this period. Upon the slightest and most unreasonable pretences, as well as upon accusations the most absurd and groundless, their persons and property were exposed to every turn of popular fury; for Norman, Saxon, Dane, and Briton, however adverse these races were to each other, contended which should look with greatest detestation upon a people, whom it was accounted a point of religion to hate, to revile, to despise, to plunder, and to persecute». ${ }^{34} \mathrm{~B}$ то же время писатель подчеркивает, что природные настойчивость и жадность евреи успешно применяют в ростовщичестве, а также наблюдательность, трусость и изобретательность является их характерологическими чертами.

Крыжановский удачно интегрируется в украинское казацкое сообщество - для этого, как мы уже писали, он принимает христианство и постепенно эмансипируется настолько, что приобретает высокую военную должность. С одной стороны, он сознательно отказывается от идентификации со своим этносом, но с другой - продолжает выполнять распространенную и привычную социальную роль украинского евреяарендатора. Его карьера, с точки зрения казацких законов, немыслима, к тому же она резко контрастирует с еще недавним временем восстаний Хмельницкого, когда евреи в Украине были жертвами казацкого террора и принудительно выкрещивались. Впрочем, смягчения запретов относительно включения евреев в казацкий реестр происходит уже со времен гетманства Мазепы, когда утихают антагонистические противоречия. ${ }^{35}$ Добавим, что преодоление этих противоречий подтверждает непрочность религиозного антисемитизма среди казаков. Со временем многие представители еврейских семей после принятия православия, соответствующей социальной

32 GROSSMAN, J. H.: The Absent Jew in Dickens: Narrators in Oliver Twist, Our Mutual Friend, and A Christmas Carol. Dickens Studies Annual, 1996, \# 24, pp. 49-50.

33 PETROV, V.: Val'ter-Skottivs'ka povist' z ukrajins'koji minuvšini. In: PETROV, V.: Rozvìdkì, T. 1. K.: Tempora, 2013, s. 278.

34 SCOTT, W.: Ivanhoe. Penguin Books, 1994, s. 69.

35 TOMAZOV, V.: Voni služili Ukrajini: Z istorïi kozac'kich rodiv jevrejs'kogo pochodžennja. Chronìka 2000, 1998, № 21-22, s. 62 . 
инкорпорации, в том числе из-за родства, попали в казацкую администрацию и в будущем формировали украинскую элиту (как скажем, роды Боруховичей, Марковичей и Герциков) и даже активно приобщались к культурному развитию украинства. ${ }^{36}$ Такое включение состоятельных евреев в казацкую верхушку объяснялось пониманием их сверхважной роли в кредитовании потребностей казачества. Как пишет С. Плохий, несмотря на устойчивые антииудейские религиозные предубеждения, старшина еще со времен Б. Хмельницкого, как и сам гетман, привыкла пользоваться административно-финансовыми услугами евреев в управлении своих владений и денежных делах, и обусловливало гибкий и прагматичный подход в «еврейском вопросе». ${ }^{37}$ В конце концов, именно такое общее восприятие евреев как арендаторов и эксплуататоров способствовало устойчивости негативных стереотипов среди населения, а в романе П. Кулиша показывается в негативных оценках Крыжановского Бардаком и судьей Животовским. То, что Крыжановский - «жид» объясняет, по мнению казаков, его коварную и дьявольскую натуру, и этого не способно изменить даже его обращения в христианство.

В образах Герцика и его матери Рохли из романа «Чайковский» Е. Гребенки представлена идея о принципиальной неспособности евреев интегрироваться в христианское общество - этому, мол, мешают не только различия в верованиях, но и присущие этой нации природные коварство, мстительность и лицемерие. В романе не противопоставляются украинцы и евреи, - противопоставляются их «врожденные» национальные характеры (как утверждает полковник Иван пойманному Герцику - «Ты говоришь как жид, смотришь как жид, а голову выстриг, итоб обмануть меня» $\left.{ }^{38}\right)$. Так, мстительность и зависть Герцика превосходят его любовь к Марине и он доносит на нее и Чайковского сечевым казакам, следуя принципу «если не мне - так никому». Кровавое возмездие руководит помыслами Рохли, которая подло отравляет больных казаков, превратившись для этого в цыганку-знахарку. Безрассудная месть за убитого мужа, отобранных у нее детей и разрушеную казацким погромом жизнь приводит к тому, что Рохля опрометчиво убивает собственного сына и сходит с ума. Показательным является и тот факт, что и в обществе разоренного еврейского городка женщина становится изгнанницей - евреи упрекают ее за якобы проданных казакам детей, а после разговора с пилигримом-евреем, и, очевидно, после его благословения, она начинает свою смертельную миссию мести православным христианам.

Оппозицию матери и брату составляет дочь и сестра - шинкарка Татьяна. Она искренне и преданно любит казака Чайковского, ради любимого готова рисковать жизнью, но, не найдя взаимности, умирает от отчаяния. Этот образ разрушает стереотипный ряд образов евреев в романе Е. Гребенки - Герцика и его товарищафальшивомонетчика Гершка, Рохли, эпизодических евреев.

36 FELLER, M.: Jeurejs'ko-ukrajins'ki vzajemini v istoričnij perspektivì. In: FELLER, M.: Narìsì z ìstorìji ta kul'turì jevrejiv Ukrajinì. K.: Duch ì Lìtera, 2009, s. 241.

37 PLOCHİJ, S.: Nalivajkova vira: Kozactvo ta religija v rann'omodernij Ukrajini. K.: Krìtìka, 2006, s. 256.

38 HREBİNKA, Je.: Čajkovskij. Roman. In: HREBİNKA, Je.: Tvorì u 3 tt . T. 2: Prozovì tvorì 1841-1845, K.: Naukova dumka, 1981, s. 282. 
В «придворном шуте» Герцике воплощена характерная черта стереотипа еврея - удивительная одаренность и талант к технике и художеству (умелость в ремонте техники спасает ему жизнь при первом знакомстве с будущим хозяином - полковником Иваном), которые часто объяснялись их «знакомством» с дьявольскими силами. Такая наивная вера украинцев в магию и колдовство евреев высмеивается в пародийной повести «Сказка о заведениях» О. Сомова, где хитрый хозяин и «мастер» Ицка Хопилевич Немировский с выгодой для себя ее используют: «Предложение сие заключено было сильными клатвенными уверениями, что он, Иика Хопьлевич Немеровский, поднял при починке плотины такие тяжкие труды, каких и предки его, би блейской памяти, не поднимали на земляной работе египетской, и что теперь плотину, по прочности укрепления и по заговору, который положил на нее этот честный еврей, не размыло бы и новым всемирным потопом». ${ }^{39}$ «Честный еврей» умело обращает простонародный стереотип на создание себе имиджа мастера на все руки и знахаря, который умеет не только исцелять, но и находить сокровища. Как пишет М. Вайскопф, все техническое умение Ицка поставлено под сомнение и одновременно дается рационалистическое объяснение еврейского «чародейства». ${ }^{40}$

Похожим к Татьяне из романа П. Кулиша является образ Ребекки из романа «Ivanhoe» В. Скотта. Она также полюбила христианина без взаимности. В момент признания о своей национальности, рыцарь Айвенго меняет приязнь к девушке на высокомерную прохладу - он, ревностный католик, даже не может себе представить возможность союза с еврейкой, которая, впрочем, также понимает свое беспомощность перед силой предубеждений: «It was not that Ivanhoe's former carriage expressed more than that general devotional homage which youth always pays to beauty; yet it was mortifying that one word should operate as a spell to remove poor Rebecca, who could not be supposed altogether ignorant of her title to such homage, into a degraded class, to whom it could not be honourably rendered». ${ }^{41}$ Правда, В. Скотт не забывает подчеркнуть «ложное» толкование евреями Священного Писания относительно богоизбранности их народа. Так, он обращает внимание на религиозные убеждения Ребекки, которая ожидает будущего дарения всех благ евреям после несчастий, выпавших на их долю. Ребекка вступает в своеобразный теологический диспут с тамплиером Буа-Гильбером и выступает в нем победительницей, указав на полное несоответствие принципов его веры и устава ордена церковников преступным намерениям молодого человека.

Упоминания о евреях в романе Е. Гребенки постоянно маркируются негативными коннотациями и сравнениями: «на станиии жиды и пол со скрипом», «заговорил со мной как с жидом», «жида и прочую мерзость били, грабили, жгли, а иерковъ не забывали», «жид нечистый», “«ей, хлопиы, - сказал полковник, - чуете, ли вы, пахнет неверною костью?» «Чуем, - отвечали молодиљ, - жидом пахнет»», «много денег, как у жида», «пришел в свою поганую хату жид Борох» и др. Интересно, что перед

39 SOMOV, O. M.: Kupalov večer: izbrannyje proizvedenija. K.: Dnipro, 1991, s. 175.

40 VAJSKOPF, M.: Pokryvalo Moiseja. Jevrejskaja tema v èpochu romantizma. Moskva: Mosty kul'tury - Gešarim, 2008, s. 168.

41 SCOTT, W.: Ivanhoe. Penguin Books, 1994, s. 300. 
смертью Герцик признается в том, что он еврей. ${ }^{42}$ Это единственный случай в романе, когда не употребляется слово «жид» - дань внедряемой в то время постепенной замене в светской (в том числе и литературной) речи этнонима «жид», который уже приобрел антисемитское, отчетливо негативное и оскорбительное значения, церковнославянским и библейским словом «еврей». (Как известно, искоренение традиции пользоваться этнонимом «жид» в официальных документах Российской империи началось с соответствующего указу Екатерины II в 1787 году по просьбе общины одного из белорусских штетлов ${ }^{43}$ ) Через три года после публикации «Чайковского», в 1846 г., Е. Гребенка публикует рассказ «Иерусалим» в коллективном сборнике «Картины русской живописи», где представляет рассказ паломника о посещении Палестины. Истории главного города иудеев в этом рассказе отбедено много места [по концептуальному замыслу редактора издания Н. Кукольника каждое произведение было своеобразным художественным описанием определенной картины (сборник сопровождался 12 гравюрами) - так, Е. Гребенка «иллюстрирует» два полотна - «Иерусалим» М. Воробьева и «Вознесение Богоматери» К. Брюллова (рассказ «Рассказ»)]. Интерпретация дохристианской истории города является изображением богоборческой деятельности его жителей, которые отходят от Божих завещаний, игнорируют предостережения ветхозаветных пророков, и, в итоге, достигают апогея своего малодушия, отдав на муки и казнь Богочеловека. С тех пор Иерусалим становится проклятым местом, испытывает немало потрясений и уже никогда не восстановит свое прежнее величие времен Израильского и Иудейского царств. Рассеяния евреев после разрушения Иерусалимского Храма римскими войсками понимается в рассказе как осуществление пророчества Иисуса Христа о упадке города. Попытки же возродить Иерусалим так и не становятся успешными, ведь этого не хочет сам Бог: «Сколько раз человеческая рука пытается воздвигнуть свое слабое здание, столько же раз рука Божия разрушает его». ${ }^{44}$

Также и В. Скотт в романе «The Surgeon's Daughter» доказывает невозможность осуществления проекта интеграции «неверных» евреев в христианское общество. Такое мнение иллюстрирует образ дочери богатого португальского еврея де Монкады. Переехав в Лондон, отец входит в столичный мир, имеет связи среди влиятельных христиан. Один из них - дворянин из знатной семьи, - просит руки Цилии, но не может побороть в себе чувство превосходства по сравнению с хоть и богатыми, но евреями, и получает резкий отказ: «Tresham made his proposals to Moncada, perhaps in a manner which too evidently showed that he conceived the high-born Christian was degrading himself in asking an alliance with the wealthy Jew». ${ }^{45}$ Впрочем, Трэшам и Цилия становятся

42 HREBİNKA, Je.: Čajkovskij. Roman. In: HREBÌNKA, Je.: Tvorì u 3 tt . T. 2: Prozovì tvorì 1841-1845, K.: Naukova dumka, 1981, s. 397.

43 BUDNICKIJ, O. V.: Jeurei v Rossijskoj imperii (1772-1917). In: DOLBILOV, M. - MILLER, A. (naučnyje redaktory): Zapadnyje okrainy Rossijskoj imperii. Moskva: Novoje literaturnoje obozrenije, 2006, s. 304.

44 HREBÌNKA, Je.: Ijerusalim. In: HREBİNKA, Je.: Tvorì u 3 tt. T. 3: Povìstì. Opovìdannja. Narìs̀̀. Stattì. Recenzìji. Lìstì, K.: Naukova dumka, 1981, s. 450.

45 SCOTT, W.: The Surgeon's Daughter [Электронный ресурс] [Режим доступа:] <http://www.gutenberg. org/files/6428/6428-h/6428-h.htm> [Дата доступа: 03.05.2015]. 
любовниками, но их разлучают, впоследствии Цилия рожает сына, который получает имя Ричард Мидлмаз. В произведении Мидлмаз становится воплощением всех низменных черт, соблазняет невинную девушку - на этот раз христианку Мени Грей, - словно сводя счеты за честь матери. В конце концов, Ричард погибает ужасной смертью, и, по мнению автора, вполне заслуженно, учитывая его злодеяния.

В проанализированных произведениях украинских писателей мы не заметили актуализации стереотипного образа еврея-арендатора с «ключами от церкви», свойственного для вертепа, интермедий и религиозных школьных драм XVIII в. и ранней исторической литературы начала XIX в., и впоследствии развитого, по наблюдению М. Шкандрия, в некоторых произведениях Н. Гоголя, Т. Шевченко, Н. Костомарова и П. Кулиша. ${ }^{46}$ В стереотипных моделях восприятия евреев в украинской и английской литературах I-й половины XIX в. есть общая основа, однако с определенными особенностями - в романах английских авторов преобладает образ еврея-ростовщика, который наживается на доверчивых христианах ( «Ivanhoe» В. Скотта, «Oliver Twist; or, The Parish Boy's Progress» Ч. Диккенса), а в произведениях украинских писателей этот образ имеет историческую составляющую - еврей является «вечным» сообщником врагов (татар, польской шляхты, представителей имперской администрации) в борьбе против Украины, и даже те, которые принимают православную веру, всегда готовы коварно предать и убить ( «айдамак» О. Сомова, «Предание о Гаркуше» Г. Квитки-Основьяненко, «Михаил Чарнишенко...» П. Кулиша, «Чайковский» Е. Гребенки). Те же образы евреев, которые демонстрируют положительные черты, так же часто, как и образы евреев-злодеев, свидетельствуют о непонимании особенностей еврейской культуры, или же ее поверхностную и потому примитивную рецепцию («Our Mutual Friend» Ч. Диккенса). Полная интеграция евреев в христианскую культуру, как правило, отвергается авторами обеих литератур ( Ivanhoe», «The Surgeon's Daughter» В. Скотта, «Чайковский» Е. Гребенки, «Михаил Чарнишенко...» П. Кулиша) именно изза стереотипных глубоких разногласий на религиозной почве.

Таким образом, образ еврея в художественных текстах В. Скотта, Ч. Диккенса, О. Сомова, Г. Квитки-Основьяненко, П. Кулиша, Е. Гребенки (часть текстов - некоторые малые прозаические произведения О. Сомова и произведения прочих авторов - В. Нарежного и др. - мы были вынуждены исключить из-за ограничений рамками статьи) часто является прототипом злодея, который происками и уловками пытается сожительствовать с своими нынешними или бывшими обидчиками, а чаще - их обмануть и уничтожить. В то же время он является униженным и бесправным изгоем в христианской общине, человеком «низшего сорта», и, даже при условии частичного вхождения в общество, например, его уголовный слой, как в случае с диккенсовским Фейгином, или в казацкую верхушку, как это показано на примере кулишовского Крыжановского, эта «врожденная» черта постоянно подчеркивается авторами. Образы же «прекрасных евреек» Ребекки и Татьяны, а также их судьбы - это демонстрация глубокой «культурно-исторической» пропасти между женщинами и их любимыми - представителями христианской

46 SHKANDRIJ, M.: Jews in Ukrainian Literature: Representation and Identity. New Haven: Yale University Press, 2009, s. 19. 
культуры. Уже в более поздний период положительные образы евреев оказались слишком неправдоподобными, чтобы войти в общую парадигму изображения еврейства в литературе - в украинской литературе, как известно, такие характеры появляются только на рубеже ХIX и XX вв.

\section{Литература}

BUDNICKIJ, O. V.: Jevrei v Rossijskoj imperii (1772-1917). In: DOLBILOV, M. - MILLER, A. (naučnyje redaktory): Zapadnyje okrainy Rossijskoj imperii. Moskva: Novoje literaturnoje obozrenije, 2006, s. 301-340.

VAJSKOPF, M.: Pokryvalo Moiseja. Jevrejskaja tema v èpochu romantizma. Moskva: Mosty kul'tury Gešarim, 2008.

HRABOVIČ, H.: Jevrejs’ka tema v ukrajins'kij litteraturi XIX ta počatku XX storiččja. In: HRABOVIČ,

H.: Do ìstorìi ukrajins'koji lìteraturì: Doslìdžennja, ese, polemika. K.: Osnovì, 1997, s. 238-258. HREBÌNKA, Je.: Ijerusalim. In: HREBÌNKA, Je.: Tvorì u 3 tt. T. 3: Povìstì. Opovìdannja. Narìsì. Stattì. Recenzìji. Lìstì, K.: Naukova dumka, 1981, s. 437-452.

HREBÌNKA, Je.: Čajkouskij. Roman. In: HREBİNKA, Je.: Tvorì u 3 tt . T. 2: Prozovì tvorì 18411845, K.: Naukova dumka, 1981, s. 275-406.

ZIMBARDO, F. - LJAJPPE, M.: Social'noje vlijanije. SPb.: Piter, 2000.

İstorija rusiv. K.: Veselka, 2003.

KAC, Ja.: Ischod iz getto: social'nyj kontekst èmansipacii jevrejev, 1770-1870. Ijerusalim: Gešarim; Moskva: Mosty kul'tury, 2007.

KVÌTKA-OSNOV’JANENKO, G. F.: Predanija o Garkuše. In: KVÌTKA-OSNOV’JANENKO, G. F.: Zìbrannja tvorìv u 7-mì t. T. 6: Prozovì tvorì. K.: Naukova dumka, 1981, s. 290-366.

KULİŠ, P. O.: Čorna rada. Michajlo Čarnǐ̌enko. K.: Personal, 2008.

LAZAREVSKIJ, A. M.: “Ljudi staroj Malorossii. 8. Kryžanowskije”. Kijevskaja starina, 1885, № 5, Maj, s. 7-13.

LIPPMAN, U.: Obščestvennoje mnenije. Moskva: Institut Fonda «Obščestvennoje mnenije», 2004.

NACHMANOVIČ, V.: Jevrei v ukrainskich narodnych pesnjach tret'jej četverti XIX v. 2011 [Èlektronnyj resurs] [Režim dostupa:] <http://historians.in.ua/index.php/doslidzhennya/46-nakhmanovich> [Data dostupa: 03.05.2015].

PETROV, V.: Val'ter-Skottius'ka povist' z ukrajins'koji minurv̌̌ini. In: PETROV, V.: Rozvìdkì, T. 1. K.: Tempora, 2013, s. 272-293.

PLOCHİJ, S.: Nalivajkova vìra: Kozactvo ta religija v rann'omodernij Ukrajini. K.: Krìtìka, 2006.

SOMOV, O. M.: Kupalov večer: izbrannyje proizvedenija. K.: Dnipro, 1991.

TOMAZOV, V.: Voni služili Ukrajini: Z istorìji kozac'kich rodìv jevrejs'kogo pochodžennja. Chronìka 2000, 1998, № 21-22, s. 62-72.

Tora. Pjatiknižije i Gaftarot. Moskva - Ijerusalim: Gešarim, 1999.

FELLER, M.: Jevrejs'ko-ukrajins'ki vzajemini v istoričnij perspektivì. In: FELLER, M.: Narìsì z ìstorìji ta kul'turì jevrejiv Ukrajinì. K.: Duch ì Lìtera, 2009, s. 232-256.

CHOREV, V.: Imagologija i izučenije russko-pol'skich literaturnych svjazej. In: CHOREV, V. A. (otv. red.): Poljaki i russkije v glazach drug druga, Moskva: Indrik, 2000, s. 22-32. 
DICKENS, Ch.: Our Mutual Friend [Электронный ресурс] [Режим доступа:] <http:/ /www2.hn. psu.edu/faculty/jmanis/dickens/friendco.pdf> [Дата доступа: 03.05.2015].

EDWARDS, A. L.: Four Dimensions in Political Stereotypes. Journal of Abnormal and Social Psychology, 1940, Vol. 35 (4), pp. 566-572.

EGAN, J. M.: The Stereotyped Jew: in English Literature. [Philadelphia, Pa.]: Xlibris, 2002.

GROSSMAN, J. H.: The Absent Jew in Dickens: Narrators in Oliver Twist, Our Mutual Friend, and A Christmas Carol. Dickens Studies Annual, 1996, \# 24, pp. 37-57.

HALES, A.: Walter Scott's Jews and How They Shaped the Nation. In: Beyond the Anchoring Grounds: More Cross-Currents in Irish and Scottish Studies. Eds. Sh. Alcobia-Murphy - J. Archbold J. Gibney - C. Jones. Belfast: Cló Ollscoil na Banríona, 2005, pp. 127-132.

HOWE, I.: Introduction. In: DICKENS, Ch.: Oliver Twist. New York: Bantam Dell, 2005, pp. XI-XII. COHEN, D. - HELLER, D. (eds.): Jewish Presences in English Literature. Montreal [Que.]: McGill-Queen's University Press, 1990.

KATZ, E. M.: Neither with Them, nor without Them: the Russian Writer and the Jew in the Age of Realism. Syracuse, N.Y.: Syracuse University Press, 2008.

KAUFMAN, H.: English Origins, Jewish Discourse, and the Nineteenth-Century British Novel: Reflections on a Nested Nation. University Park, Pa.: Pennsylvania State University Press, 2009.

LIVAK, L.: The Jewish Persona in the European Imagination: a Case of Russian Literature. Stanford, Calif.: Stanford University Press, 2010.

MONTAGU, F. M.: The Jew in the Literature of England to the End of the 19th Century. New York: Meridian Books, 1960.

PAGE, J. W.: Imperfect Sympathies: Jews and Judaism in British Romantic Literature and Culture. New York: Palgrave Macmillan, 2004.

PANITZ, E. L.: The Alien in Their Midst: Images of Jews in English Literature. Rutherford [N. J.]: Fairleigh Dickinson University, 1981.

ROSENBERG, E.: From Shylock to Svengali; Jewish Stereotypes in English Fiction. Stanford, Calif.: Stanford University Press, 1960.

SCOTT, W.: Ivanhoe. Penguin Books, 1994.

SCOTT, W.: The Surgeon's Daughter [Электронный ресурс] [Режим доступа:] <http://www. gutenberg.org/files/6428/6428-h/6428-h.htm> [Дата доступа: 03.05.2015].

SCRIVENER, M. H.: Jewish Representation in British Literature 1780-1840: after Shylock. New York: Palgrave Macmillan, 2011.

SHKANDRIJ, M.: Jews in Ukrainian Literature: Representation and Identity. New Haven: Yale University Press, 2009.

SPECTOR, Sh. A.: The Jews and British Romanticism. New York: Palgrave Macmillan, 2005.

STONE, H.: Dickens and the Jews. Victorian Studies, 1959, Vol. 2, No. 3, pp. 223-253.

\section{доцент Денис Чабович Чик, кандидат филологических наук}

ул. С. Петлюры д. 18 кв. 53, г. Кременец Тернопольская обл. Украина 47004

denyschyk@ukr.net

dennys@meta.ua 
Денис Чабович Чик

Стереотип еврея в украинской и английской прозе I-й половины XIX в.

doc. Denis Čabovič Čik, kandidat filologičeskich nauk

ul. S. Petljury d. 18. kv. 53, g. Kremenec Ternopol'skaja obl. Ukraina 47004 